\title{
Article \\ Evaluation of Fe-Mg Binary Oxide for As (III) Adsorption-Synthesis, Characterization and Kinetic Modelling
}

\author{
Saif Ullah Khan ${ }^{1, *(\mathbb{D})}$, Rumman Zaidi ${ }^{2}{ }^{(\mathbb{D}}$, Feroz Shaik ${ }^{3, *(\mathbb{D})}$, Izharul Haq Farooqi ${ }^{1}$, Ameer Azam ${ }^{2}$, \\ Hatem Abuhimd ${ }^{4}$ and Faheem Ahmed ${ }^{5}{ }^{(B)}$ \\ 1 Department of Civil Engineering, Zakir Husain College of Engineering \& Technology, \\ Aligarh Muslim University, Aligarh 202002, India; farooqi_izhar@yahoo.com \\ 2 Department of Applied Physics, Zakir Husain College of Engineering \& Technology, \\ Aligarh Muslim University, Aligarh 202002, India; rumman.zaidi11@gmail.com (R.Z.); \\ azam2288@gmail.com (A.A.) \\ 3 Department of Mechanical Engineering, Prince Mohammad Bin Fahd University, P.O. Box 1664, \\ Al Khobar 34754, Saudi Arabia \\ 4 National Nanotechnology Center, King Abdulaziz City for Science and Technology, P.O. Box 6086, \\ Riyadh 11442, Saudi Arabia; habuhimd@kacst.edu.sa \\ 5 Department of Physics, College of Science, King Faisal University, P.O. Box 400, Hofuf, \\ Al-Ahsa 31982, Saudi Arabia; faheem030@gmail.com \\ * Correspondence: saifkhan@zhcet.ac.in (S.U.K.); ferozs2005@gmail.com (F.S.)
}

check for

updates

Citation: Khan, S.U.; Zaidi, R.; Shaik, F.; Farooqi, I.H.; Azam, A.; Abuhimd, H.; Ahmed, F. Evaluation of Fe-Mg Binary Oxide for As (III) Adsorption-Synthesis, Characterization and Kinetic Modelling. Nanomaterials 2021, 11, 805. https://doi.org/10.3390/ nano11030805

Academic Editor: George Z. Kyzas

Received: 21 December 2020

Accepted: 4 March 2021

Published: 21 March 2021

Publisher's Note: MDPI stays neutral with regard to jurisdictional claims in published maps and institutional affiliations.

Copyright: (c) 2021 by the authors. Licensee MDPI, Basel, Switzerland. This article is an open access article distributed under the terms and conditions of the Creative Commons Attribution (CC BY) license (https:// creativecommons.org/licenses/by/ $4.0 /)$.

\begin{abstract}
Nanotechnology has received much attention in treating contaminated waters. In the present study, a facile co-precipitation method was employed to synthesize a novel iron and magnesium based binary metal oxide using a stoichiometrically fixed amount of $\mathrm{FeNO}_{3} \cdot 9 \mathrm{H}_{2} \mathrm{O}$ and $\mathrm{MgNO}_{3} \cdot 6 \mathrm{H}_{2} \mathrm{O}$ in a proportion of molar concentration 1:1 and was later evaluated in removing As (III) from contaminated waters. Characterization of the prepared nanomaterial was done using X-ray diffraction (XRD), scanning electron microscopy (SEM), Energy Dispersive X-ray Analysis (EDAX) and ultraviolet-visible spectrophotometry (UV-VIS). Experimental studies on batch scale were carried out, examining the effect of varying initial concentrations of metal, adsorbent dosage, application time and initial $\mathrm{pH}$ on removal efficiency. Arsenic removal increased on increasing adsorbent dosage $(0.1-1 \mathrm{~g} / \mathrm{L})$ but trend reversed on increasing initial arsenic concentration attaining $\mathrm{q}_{\mathrm{max}}$ of $263.20 \mathrm{mg} / \mathrm{g}$. Adsorption was quite efficient in $\mathrm{pH}$ range 4-8. Freundlich fitted better for adsorption isotherm along with following Pseudo-2nd order kinetics. The reusability and effect of co-existing ions on arsenic adsorption, namely $\mathrm{SO}_{4}{ }^{2-}, \mathrm{CO}_{3}{ }^{2-}$ and $\mathrm{PO}_{4}{ }^{3-}$ were also explored with reusability in 1st and 2nd cycles attained adsorptive removal up to $77 \%$ and $64 \%$ respectively. The prepared nano-adsorbent showed promising results in terms of high arsenic uptake (qmax of $263.20 \mathrm{mg} / \mathrm{g}$ ) along with facile and cost-effective synthesis. Thus, the co-precipitation technique used in this work is a simple one step procedure without any use of any precursor as compared to most of the other procedures used for synthesis.
\end{abstract}

Keywords: arsenic contamination; nano-particle synthesis; binary metal oxide; co-existing ions; adsorption mechanism

\section{Introduction}

Arsenic is a well known carcinogen present in water supplies all around the globe. It is prioritized as one of the top 20 hazardous substance by Agency for Toxic Substances and Disease Registry [1]. It has been reported recently in countries like China, India, Taiwan, Poland, Argentina, Japan, New Zealand, Mexico, Hungary, Canada and USA [2]. Regulatory bodies like the World Health Organization (WHO) has a directed permissible limit of arsenic as $10 \mathrm{ppb}$ in drinking water [3]. Arsenic exists mostly in inorganic form 
besides organic as well; however the predominant forms of inorganic arsenic found in surface and ground water are arsenite and arsenate [4]. Among these two, arsenite [As (III)] is considered more toxic, as well as mobile, than arsenate, thereby drawing attention worldwide [5]. Arsenite comprises of a neutral state of arsenic species like $\mathrm{HAsO}_{3}{ }^{0}$ as compared to arsenate species like $\left(\mathrm{H}_{2} \mathrm{AsO}_{4}{ }^{-}, \mathrm{HAsO}_{4}{ }^{2-}\right)$, as a result of which adsorption and other techniques generally prove less effective in removing As (III) [5]. Ingesting water that contains arsenic beyond the permissible limit for longer durations causes ill health effects, mainly cancer of skin, kidneys and lungs beside others [1].

With the technological advancements, researchers with a focus on separation techniques have used various methods for arsenic removal, including ion exchange, chemical reduction, reverse osmosis, electrochemical means, modified coagulation/filtration and adsorption, which are few among so many [6]. But these conventional approaches have one or the other drawbacks: low efficiency, requiring chemicals, huge energy consumption and extensive sludge generation [7]. With such constraints, adsorption based approaches have a wider acceptability due to ease of operation, higher efficiency and cost effectiveness [8,9].

Ongoing research on nano-sized adsorbents has attracted a lot of attention as these possess a large surface area offering a large number of active sites to bind upon [10]. The smaller the size, the larger the surface area available, thus enhancing the adsorption over their surface [11]. But still, the separation and regenerative ability of nanoparticles is a concern [12]. Several adsorbents have been reported to adsorb arsenic effectively with a focus shifting towards metal oxide based sorbents such as titanium [13], aluminum [14], zirconium [15], iron [16], and so forth. Among these, iron based sorbents were extensively studied due to greater affinity, cost effectiveness and environmental suitability [17].

In recent times, the development of adsorbents based on two or more metal oxides has attracted the attention of researchers worldwide, as binary oxide not only procures the characteristics of the parent compound but also displays synergistic effects [18]. This synergistic effect is evident from the enhanced adsorption capability in many recent studies $[19,20]$. For example, Fe-Mn binary oxides were found to be successful in removing arsenic ions from groundwater [21]. Another group of researchers, (An and Zhao. 2012) prepared a new class of Fe-Mn binary oxide with water soluble starch as a stabilizer for the adsorptive removal of both arsenite and arsenate [22]. Similarly, (Ren et al. 2011) prepared a Fe-Zr binary oxide that has high adsorption capacity for arsenic [3]. Another research work on synthesizing a Fe-Ce binary oxide for the possible adsorption of arsenic was explored [23]. In another study, (Khan et al. 2016) prepared a novel iron and copper based binary oxide nanomaterial for the efficient sorption of Cr (VI) [24]. Moreover, aiming at multiple contaminants, a Fe-Ce binary magnetic mesoporous metal oxide adsorbent was synthesized exhibiting simultaneous removal of $\mathrm{Cr}$ (VI) and As (III) [25]. The use of magnesium as an adsorbent has also been used in the past for containment of heavy metal discharge $[16,26]$. Even the triple metal composite of Fe-Mg-La has been successfully synthesized with magnesium as an important component for the adsorption of contaminants such as fluoride [27].

Therefore, coming up with developing novel, effective and reliable alternative, Fe (III)Mg (II) binary oxide nano-adsorbent was prepared. A co-precipitation technique was adopted as it is a simple one step procedure without any use of any precursor as compared to most of the other procedures used for synthesis. Thus, our aim is to: (1) propose a simple method of co-precipitation to prepare this binary metal oxide nano-adsorbent at room temperature; (ii) to characterize the prepared adsorbent nanomaterial; (iii) to evaluate the As (III) removal efficiency by prepared nanomaterial in terms of adsorption capacity and study the adsorption kinetics as well as factors affecting it.

\section{Materials and Methods}

\subsection{Chemicals and Instrumentation}

Synthetic solutions of known arsenic concentration [As (III)] were prepared by dissolving $\mathrm{NaAsO}_{2}$ (Sigma-Aldrich, Saint louis, MI, USA) in deionized water. The beakers 
were air tight and covered with silver foil along with centrifuge tubes to avoid oxidation reactions resulting in conversion to As (V). Batch studies were carried out to investigate the suitability of prepared adsorbent in uptaking As (III). Arsenic concentration was determined throughout the study using Inductively coupled plasma mass spectrometry (ICP-MS) (PerkinElmer NexION 2000).

Synthesis of nanomaterial was carried out using ferric nitrate nonahydrate $\left(\mathrm{FeNO}_{3} \cdot 9 \mathrm{H}_{2} \mathrm{O}\right)$ (Sigma-Aldrich), magnesium nitrate hexahydrate $\left(\mathrm{MgNO}_{3} \cdot 6 \mathrm{H}_{2} \mathrm{O}\right)$ (Sigma-Aldrich). For X-ray diffraction (XRD), Rigaku Miniflex X ray diffractometre (HyPix-400 MF) with $\mathrm{Cu}-\mathrm{K} \alpha$ rays was used for characterizing the prepared adsorbent. Fourier Transform Infrared Spectroscopy (FT-IR) was carried out by spectrophotometer (Perkin Elmer Spectrum 100). Scanning electron microscopy (SEM) for studying the morphology of the prepared material was done by electron microscope (SEM- JEOL JSM 6510LV). Optical properties were studied through ultraviolet-visible spectrophotometry (UV-VIS) spectrophotometer.

\subsection{Nano-Adsorbent Synthesis}

The binary Fe (III)-Mg (II) nanomaterial was synthesized at room temperature using iron and magnesium salts. In a typical synthesis method, stoichiometrically, a fixed amount of $\mathrm{FeNO}_{3} \cdot 9 \mathrm{H}_{2} \mathrm{O}$ and $\mathrm{MgNO}_{3} \cdot 6 \mathrm{H}_{2} \mathrm{O}$ were mixed in the proportion of molar concentration 1:1 dissolved in double distilled water. The sample was agitated for $2 \mathrm{~h}$. Furthermore, drops of ammonia solutions $(3 \mathrm{~mol} / \mathrm{L})$ were added to raise the $\mathrm{pH}$ to about 8 , thus initiating precipitation of Fe (III)-Mg (II) oxides. The suspension formed was constantly stirred for $45 \mathrm{~min}$, matured at room temperature for $24 \mathrm{~h}$ before washing it by de-ionized water. The dried powder obtained was calcined at $500{ }^{\circ} \mathrm{C}$ for $2 \mathrm{~h}$ and grinded in a mortar to obtain a fine powder. The magnetic properties, particle size and crystallinity of magnetite and magnesium oxide nanoparticles are very sensitive to the annealing temperature [28]. Annealing temperature was chosen by carefully reviewing the literature to obtain the final crystalline phases $[29,30]$. The resultant suspension was filtered and dried at $80{ }^{\circ} \mathrm{C}$ for $24 \mathrm{~h}$. Finally, the material was finely ground and crushed to obtain the powdered form.

\section{Results}

\subsection{Characterization by Structural Properties: (XRD)}

X-ray diffraction (XRD) patterns were recorded in a Rigaku X-ray Diffractometer equipped with a graphite monochromator using $\mathrm{CuK} \alpha$ radiation, $40 \mathrm{kV}$ and $40 \mathrm{~mA}$ in the $2 \theta$ range $10-80^{\circ}$. $X^{\prime}$ pert highscore plus software of version 3.0 was used to identify and match the peaks. The X-ray diffraction pattern of the prepared $\mathrm{Fe}_{3} \mathrm{O}_{4}-\mathrm{MgO}$ binary metal oxide in 1:1 prepared by a simple, low cost co-precipitation technique is shown in Figure 1. The peak positions in the observed XRD pattern were well aligned with the literature data of both the metal oxides. The sharp and relatively strong intensive diffraction peaks reflect the highly crystalline nature of the samples. In the XRD pattern produced, all the peaks noted were attributed to either $\mathrm{MgO}$ or $\mathrm{Fe}_{3} \mathrm{O}_{4}$ facets, demonstrating that the diffraction pattern acquired is well compatible with the cubic lattice for both metal oxides, which establishes the lack of any other phases as impurities. The prepared material XRD pattern displays the diffraction peaks for iron oxide (marked red), that are observed near the 2 theta values of $18.5^{\circ}, 33.6^{\circ}, 37.1^{\circ}, 43.4^{\circ}, 45^{\circ}, 59.4^{\circ}, 61.1^{\circ}, 65.4^{\circ}$ with the crystal planes of (111), (022), (113), (222), (004), (115), (333), (044) for the synthesized samples (Reference code:96-901-3201, COD code: 9002331). The major peaks for MgO were detected in the XRD pattern $37.7^{\circ}, 38.8^{\circ}, 44.1^{\circ}$ and $63.5^{\circ}$ with the crystal planes of $(111),(002),(022)$ respectively. It is well matched with Reference code: 96-901-3201, COD code: 9013200 . The XRD findings suggest that a few of the of the magnesium oxide crystal plane diffraction peaks were being overlapped with iron oxide peaks, with some significant magnesium oxide peaks appearing in the $\mathrm{Fe}_{3} \mathrm{O}_{4}-\mathrm{MgO}$ XRD pattern confirming the presence of $\mathrm{MgO}$ on the $\mathrm{Fe}_{3} \mathrm{O}_{4}$ surface. Therefore, the prepared material is a blend of the individual phases of binary oxide that co-exist in one substance. These results are similar to other binary oxides in previous 
studies [31-34]. The weight percentage of $\mathrm{Fe}_{3} \mathrm{O}_{4}-\mathrm{MgO}$ binary metal oxide calculated was found to be $63.4 \%$ and $36.6 \%$, respectively.

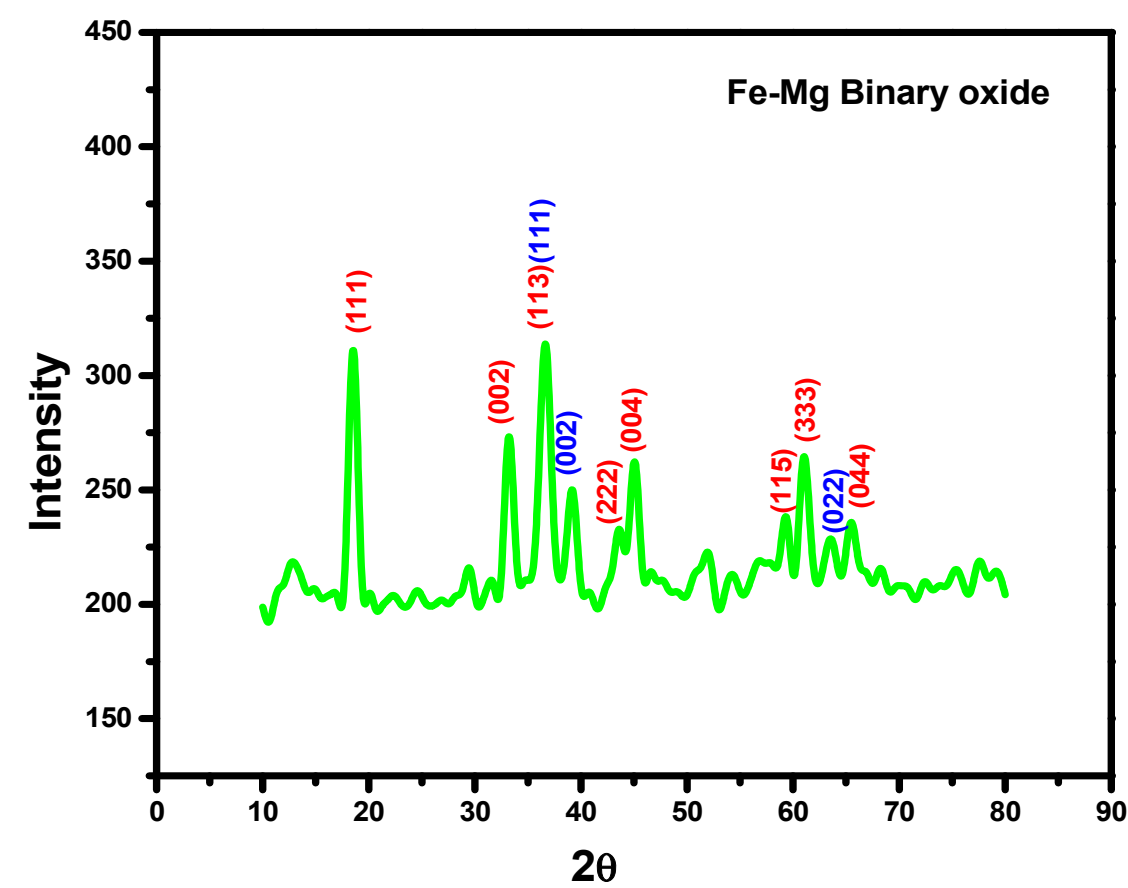

Figure 1. X-ray diffraction (XRD) pattern of Fe-Mg binary oxide nanoparticles.

The average crystallite size of the synthesized sample is calculated by using Debyee Scherrer's formula given in Equation (1) [35,36].

$$
D=\frac{0.9 * \lambda}{\beta \operatorname{Cos} \theta}
$$

where $D$ is average particle size, $\theta$ is Bragg's angle, $\beta$ is full width half maxima (FWHM), $\lambda$ is the wavelength of $\mathrm{CuK} \alpha$ radiations.

Crystallite size was calculated from the peak that has overlapping of crystal planes (111) (113) of iron and magnesium oxides. The average crystallite size thus obtained for $\mathrm{Fe}_{3} \mathrm{O}_{4} / \mathrm{MgO}$ nanomaterial was found to be $14 \mathrm{~nm}$.

For comparison and better understanding, crystallite size was also calculated by William-Hall (WH) method. The crystallite size (D) and microstrain contribute to the line broadening in X-ray diffraction. William-Hall (WH) proposed a relation between crystallite size $(D)$ and strain $(\varepsilon)$ induced broadening as given by Equation $(2)[35,37]$.

$$
\beta \operatorname{Cos} \theta=\frac{0.9 \lambda}{D}+4 \varepsilon \operatorname{Sin} \theta,
$$

where $\lambda$ is $\mathrm{X}$-ray wavelength, 0.9 is shape, and $\varepsilon$ is induced strain in crystal, $\beta$ is the FWHM in radians. To calculate crystallite size and lattice strain of the prepared material, a graph is plotted between $\beta \cos \theta$ on y-axis and $4 \sin \theta$ on $\mathrm{x}$-axis as shown in Figure 2 . The average crystallite size and lattice strain was obtained from the slope and intercept by linear fitting of the graph respectively. A comparison between crystallite size obtained from Debye-Scherrer relation and William-Hall plots shows that crystallite size calculated from Williamson-Hall plot is slightly larger than that from Scherrer relation. This difference in the size of the crystallite is mainly due to the presence of lattice strain in the samples. 


\subsection{FTIR Studies}

To examine the prepared nanomaterial compositions, FTIR studies were carried out via the $\mathrm{KBr}$ pellet method using a Nicolet FTIR spectrophotometer with a scale of $400-4000 \mathrm{~cm}^{-1}$ as depicted in Figure 3. The strong and broad band at $3390 \mathrm{~cm}^{-1}$ indicates the presence of water on the nanoparticle surface, and the vibration band at $1632 \mathrm{~cm}^{-1}$ and $1072 \mathrm{~cm}^{-1} \mathrm{can}$ be attributed to the contribution from the $\mathrm{OH}$ bending vibration modes [38]. A vibration band observed at $1428 \mathrm{~cm}^{-1}$ can be due to the $\mathrm{CO}_{3}{ }^{2-}$ stretching frequency due to the adsorption of gaseous -phase $\mathrm{CO}_{2}[39,40]$. It is important to note that the peak observed at 598, which can be assigned to $\mathrm{Fe}-\mathrm{O}-\mathrm{Fe}$ stretching modes, has shifted to a higher frequency from 570 when mixed oxides of Fe-Mg are formed [39,41-44]. The bands that appeared at low frequencies of 860 and $441 \mathrm{~cm}^{-1}$ correspond to stretching vibrations of $\mathrm{Mg}-\mathrm{O}-\mathrm{Mg}$ bonding also shows a shift towards a higher frequency range, which corresponds with previously reported work [38,45-47]. These results indicate the formation of nano Fe-Mg mixed oxides.

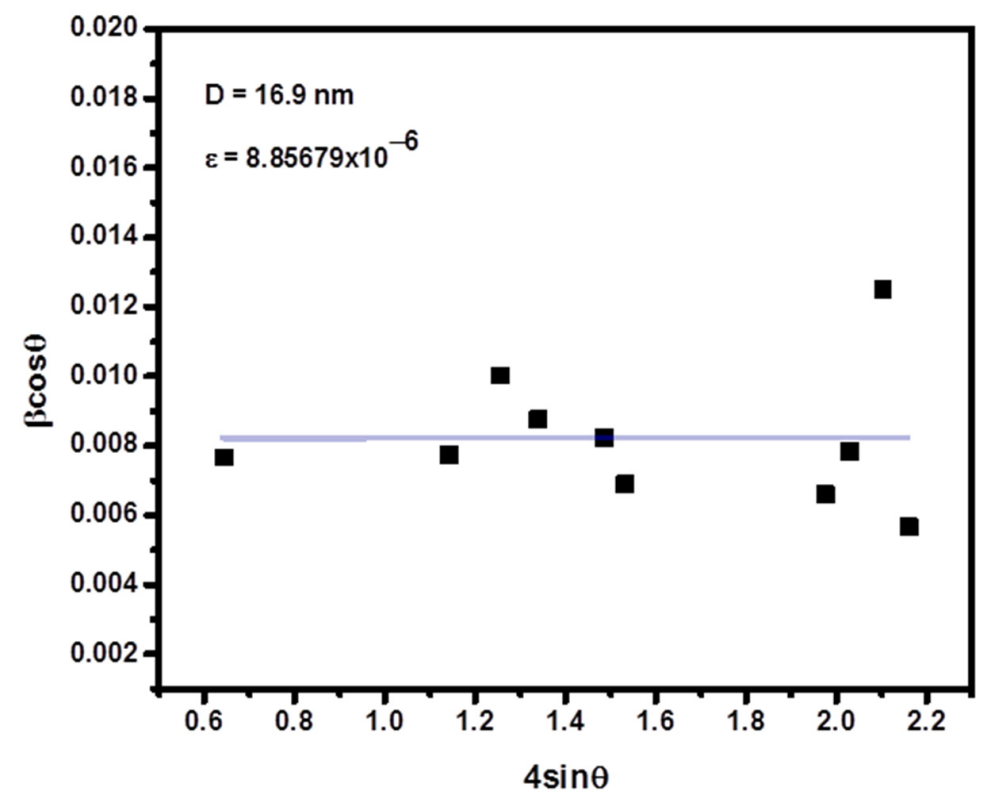

Figure 2. Williamson-Hall plot (W-H analysis) of Fe-Mg binary oxide nanoparticles.

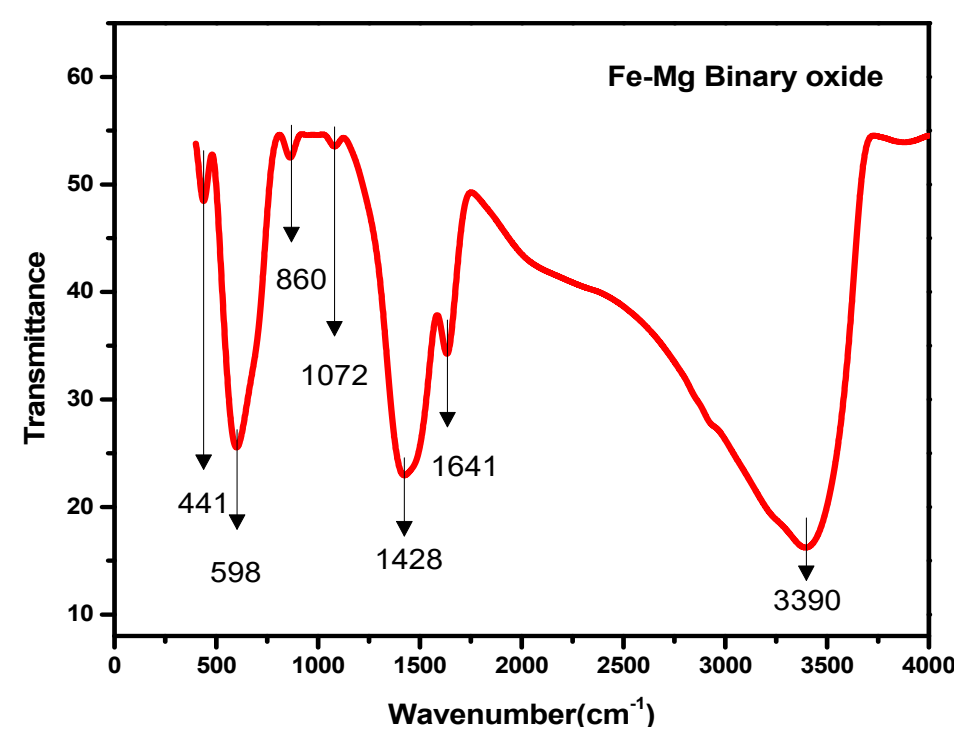

Figure 3. Fourier Transform Infrared Spectroscopy (FTIR) spectrum of Fe-Mg Binary Oxide Nanoparticles. 


\subsection{SEM with EDAX}

The morphological structures of prepared nanomaterial before and after adsorption of As (III) can be seen in Figure 4a,b using scanning electron microscopy analysis of powdered samples. Powdered sample was made to stick on the holder and was gold coated with sputter coater. SEM images before adsorption as visible in Figure 4a showing the presence of rhombohedra shaped aggregates, whereas after adsorption change in morphology showing more aggregation and presence of arsenic adsorbed over surface presumably in the form of hydroxides in Figure $4 \mathrm{~b}$. Spectrum graphs as shown in Figure 4c,d obtained from EDAX analysis for pre and post adsorption, confirming the adsorption of arsenic on the surface of Fe (III)-Mg (II) binary oxide nanoparticles.

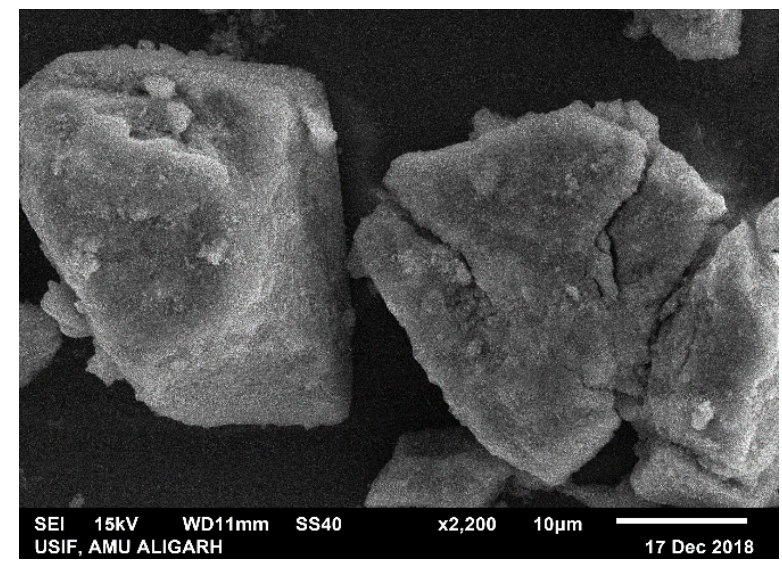

(a)

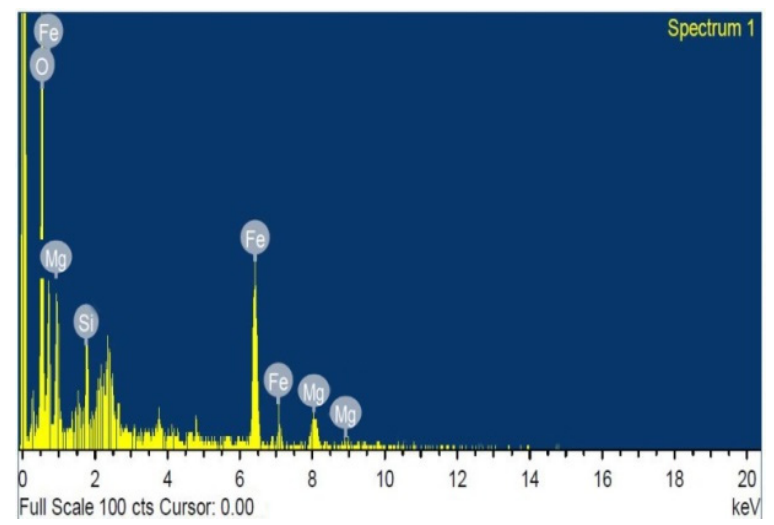

(c)

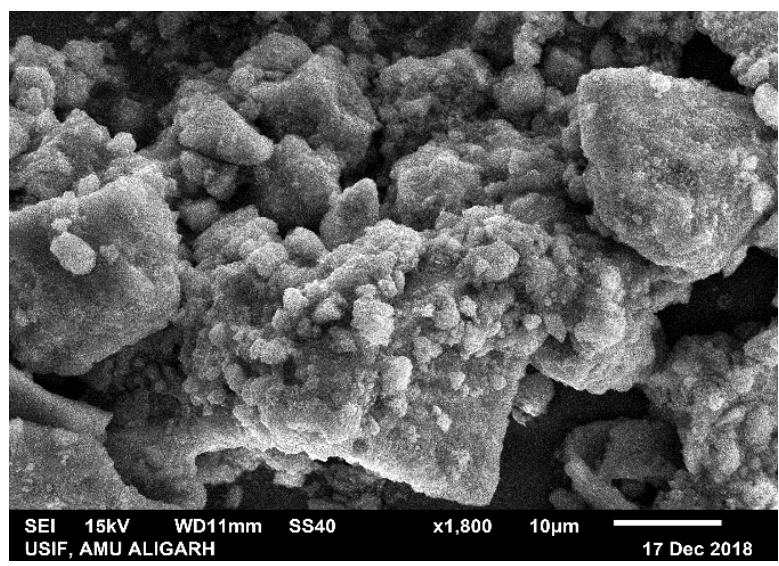

(b)

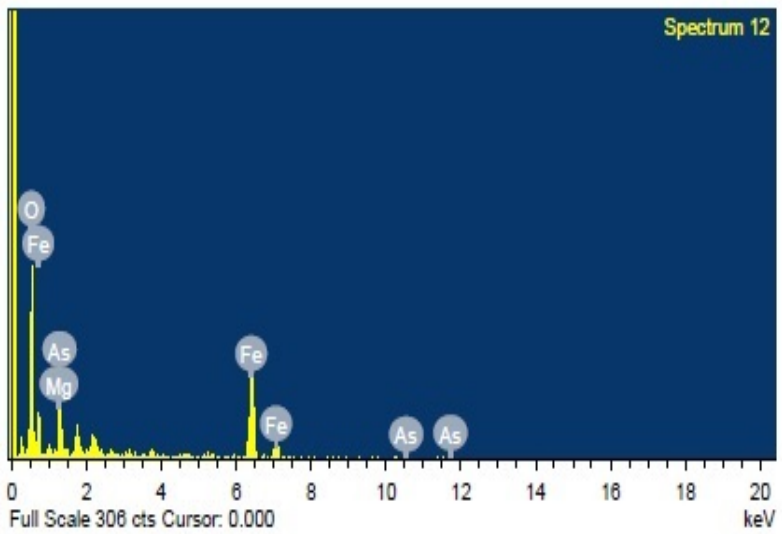

(d)

Figure 4. (a) Scanning electron microscopy (SEM) image of Fe (III)-Mg (II) binary oxide Np's before adsorption, (b) SEM images after As (III) adsorption, (c) Spectrum from EDAX before adsorption of As (III), (d) Spectrum from EDAX showing presence of As (III) along with Fe and Mg after adsorption.

\subsection{Adsorption Experiments}

Batch level studies were performed by varying As (III) concentrations and amounts of the adsorbent. The factors influencing the behavior of adsorption were explored obtaining breakthrough curves for certain fixed time durations so as to achieve equilibrium. The results obtained and plots drawn showed that prepared Fe (III)-Mg (II) binary oxide adsorbent exhibited a maximum adsorption capacity of $263.2 \mathrm{mg} \mathrm{g}^{-1}$ at $\mathrm{pH}$. The $\mathrm{pH}$ of the aqueous medium had a resilient effect on adsorption process with higher efficiency in the range of 5-7. The maximum removal efficiency of $97.6 \%$ was achieved for $10 \mathrm{mg} \mathrm{L}^{-1}$ arsenic concentration at an adsorbent dose of $1 \mathrm{~g} / \mathrm{L}$ and $\mathrm{pH}$. The experimental results were repeated and found to be within $\pm 5 \%$ error. 


\subsection{Effect of $\mathrm{pH}$ and Proposed Adsorption Mechanism}

The adsorption of arsenic is greatly affected by the $\mathrm{pH}$ of the solution [4]. As is clear from Figure 5, adsorption of As (III) is higher and more effective in the range of $\mathrm{pH} 4-8$. The maximum adsorption was found to be $137.6 \mathrm{mg} / \mathrm{g}$ at $\mathrm{pH}$ around 6 . Thus we can say that adsorption is $\mathrm{pH}$ dependent and reduces abruptly as $\mathrm{pH}$ reaches 8-9. This phenomenon is found in accordance with several past studies carried out on the adsorption of arsenic on several iron oxides $[3,48]$. The mechanism behind As (III) removal is mainly adsorption and co-precipitation of arsenic with metal hydroxides such as iron and magnesium [1,49]. Adsorption of acid anions by oxides and hydroxides of metal usually declines as $\mathrm{pH}$ becomes highly basic [50]. It signifies that the prepared nanomaterial had a high reactivity at $\mathrm{pH}$ around 6. Moreover, at a lower $\mathrm{pH}$ (lower than $\mathrm{pH}$ of $\mathrm{pzc}$ ), the nano-adsorbent surface will have additionally positive charges. However, arsenate comprising of $\mathrm{H}_{2} \mathrm{AsO}_{4}{ }^{-}$ and $\mathrm{HAsO}_{4}{ }^{2-}$ are the dominant negatively charged arsenic species present in the form of in the acidic medium. Thus, enhanced arsenic removal by synthesized iron magnesium binary oxide nanomaterial at lower $\mathrm{pH}$ shows affinity between the positively charged surface of nanomaterial and the negatively charged species of arsenic.

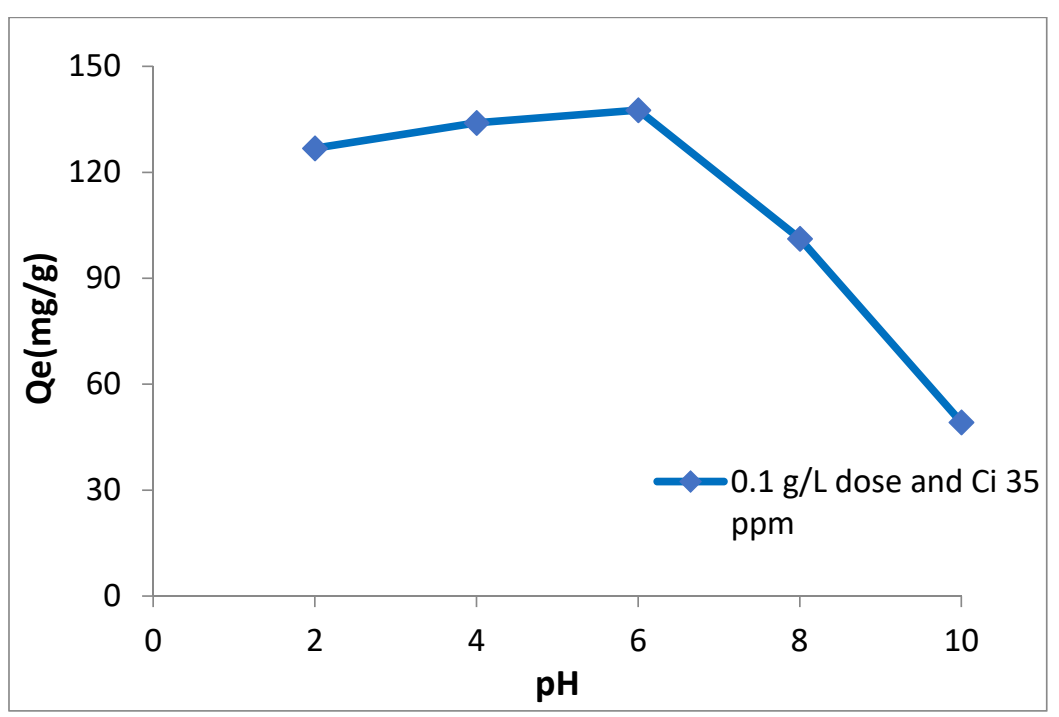

Figure 5. Effect of solution $\mathrm{pH}$ on As (III) adsorption by Fe (III)-Mg (II) binary metal oxide nanomaterial at initial As concentration of $35 \mathrm{mg} / \mathrm{L}$ and adsorbent dosage $0.1 \mathrm{~g} / \mathrm{L}$.

Both $\mathrm{As}(\mathrm{III})$ and $\mathrm{As}(\mathrm{V})$ exist as negatively charged species such as $\mathrm{HAsO}_{4}{ }^{2-}, \mathrm{AsO}_{4}{ }^{3-}$, $\mathrm{H}_{2} \mathrm{AsO}_{3}{ }^{-}$, and $\mathrm{HAsO}_{3}{ }^{2-}$. It is presumed that binary metal oxide nanoparticles in the aqueous solution would coordinate with hydroxyl ions and neutral water molecules. The process of the adsorption of arsenic onto the $\mathrm{Fe}_{3} \mathrm{O}_{4}-\mathrm{MgO}$ surface can be understood through the proposed ligand exchange mechanism. The exchange process might involve ligands, such as hydroxyl ions or neutral water molecules, existing in the metal oxide-coordinated sphere. Hence, the adsorption of arsenic might take place by the release of a hydroxyl anion or neutral water molecules from its coordinated sphere. The mechanism that might be responsible for the adsorption of the arsenic anion, that may be understood by the following equations (Equations (3)-(10)) as evident in papers by other researchers [51-55].

$$
\begin{gathered}
\mathrm{Fe}_{3} \mathrm{O}_{4}-\mathrm{MgO} \equiv \mathrm{M} \\
\equiv \mathrm{M}-\mathrm{OH}+\mathrm{H}_{3} \mathrm{AsO}_{3} \rightarrow \mathrm{FeH}_{2} \mathrm{AsO}_{3}+\mathrm{H}_{2} \mathrm{O} \\
\equiv 2[\mathrm{MOH}]+\mathrm{H}_{3} \mathrm{AsO}_{3} \rightarrow \mathrm{MHAsO}_{3} \mathrm{M}+2 \mathrm{H}_{2} \mathrm{O} \\
\equiv \mathrm{MOH}+\mathrm{H}_{2} \mathrm{AsO}_{3}^{-} \rightarrow \mathrm{MHAsO}_{3}^{-}+\mathrm{H}_{2} \mathrm{O} \\
\equiv 2[\mathrm{MOH}]+\mathrm{H}_{2} \mathrm{AsO}_{3}^{-} \rightarrow \mathrm{MHAsO}_{3} \mathrm{M}+\mathrm{HO}^{-}+\mathrm{H}^{+}
\end{gathered}
$$




$$
\begin{gathered}
\equiv \mathrm{MOH}+\mathrm{H}_{3} \mathrm{AsO}_{4} \rightarrow \mathrm{MH}_{2} \mathrm{AsO}_{4}+\mathrm{H}_{2} \mathrm{O} \\
\equiv \mathrm{MOH}+\mathrm{H}_{2} \mathrm{AsO}_{4}^{-}+\mathrm{H}_{2} \mathrm{O} \\
\equiv \mathrm{MOH}+\mathrm{HAs}_{4}^{2-} \rightarrow \mathrm{MAs}_{4}^{2-}+\mathrm{H}_{2} \mathrm{O} .
\end{gathered}
$$

\subsection{Effect of Dosage and Initial As (III) Concentration on Kinetics}

The influence of dosage and initial metal concentration on As (III) adsorption with time was studied on changing the adsorbent dosages from 0.1 to $1 \mathrm{~g} / \mathrm{L}$ and initial concentrations from $10-50 \mathrm{mg} / \mathrm{L}$. Figure $6 \mathrm{a}, \mathrm{b}$ gives the decrease in arsenic concentration by varying dosage and initial concentration with time. The equilibrium was achieved around $3 \mathrm{~h}$ in this case. From the graph (Figure 6), the sharp fall in peaks clearly indicates that the uptake capacity of the adsorbent reduces with time as the available sites for adsorption get exhausted after $3 \mathrm{~h}$ duration of reaction time. Adsorbent dosage greatly affects the adsorption of arsenic because of an overall increase in surface area of prepared binary oxide nanoparticles, due to higher availability of binding sites which is in accordance with several past studies [56].
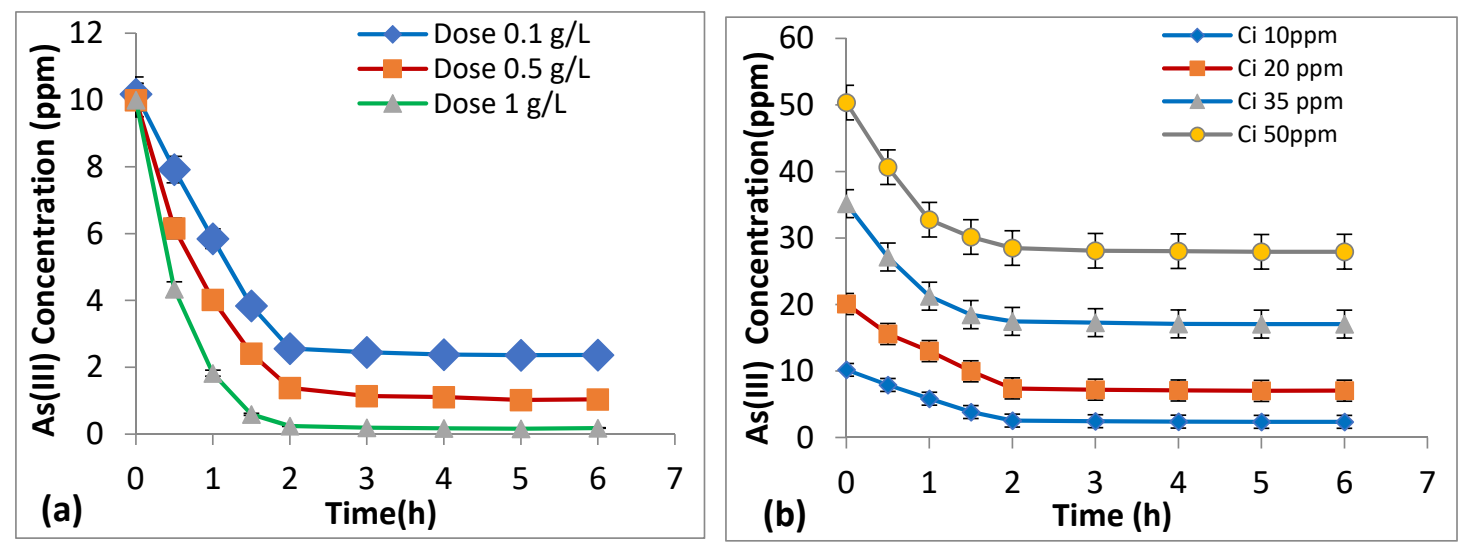

Figure 6. Adsorption kinetics for decrease in As (III) concentration with time at $\mathrm{pH} 6$ and room temperature: (a) adsorption isotherm for different adsorbent dosages (0.1-1.0) g/ $\mathrm{L}$ and initial As (III) conc. $10 \mathrm{mg} / \mathrm{L}$ w.r.t. time. (b) Adsorption isotherm at varying conc. (10-50) $\mathrm{mg} / \mathrm{L}$ and adsorbent dose of $0.1 \mathrm{~g} / \mathrm{L}$.

\subsection{Kinetics and Isotherm Modeling}

Langmuir and Freundlich Isotherm

Experiments were carried out at optimized $\mathrm{pH}$ around 6 at room temperature to acquire data for plotting isotherms. Adsorption capacity was found to increase as more time was needed to reach the saturation point by adsorbent to adsorb maximum arsenic until the equilibrium was achieved. Both, linear and non-linear models of adsorption isotherm were plotted for the initial dosage $(0.5$ and 1$) \mathrm{g} / \mathrm{L}$ of adsorbent and concentration $(10-50) \mathrm{mg} / \mathrm{L}$ of As (III) as shown in the Figures 7 and 8 . Adsorption isotherms were drawn to know the best fit for both Langmuir and Freundlich models $[57,58]$. The linearized forms of isotherm models are as follows:

$$
\begin{gathered}
\ln \left(\mathrm{q}_{\mathrm{e}}\right)=\ln \left(\mathrm{K}_{\mathrm{f}}\right)+\frac{1}{\mathrm{n}} \mathrm{C}_{\mathrm{e}} \cdot(\text { Freundlich equation }) \\
\frac{\mathrm{C}_{\mathrm{e}}}{\mathrm{q}_{\mathrm{e}}}=\frac{1}{\mathrm{q}_{\max } \mathrm{b}}+\frac{\mathrm{C}_{\mathrm{e}}}{\mathrm{q}_{\max }} \cdot(\text { Langmuir equation }) .
\end{gathered}
$$

The non-linear isotherm models are as follows:

$$
\begin{aligned}
\mathrm{q}_{\mathrm{e}} & =\mathrm{K}_{\mathrm{f}} \mathrm{C}_{\mathrm{e}}^{1 / n} \cdot(\text { Freundlich equation }) \\
\mathrm{q}_{\mathrm{e}} & =\frac{\mathrm{q}_{\max } \mathrm{bC}_{\mathrm{e}}}{1+\mathrm{bC}_{\mathrm{e}}} \cdot(\text { Langmuir equation }),
\end{aligned}
$$


where;

$\mathrm{q}_{\mathrm{e}}=$ adsorption capacity (the mass of adsorbate adsorbed over adsorbent at equilibrium), $\mathrm{mg} / \mathrm{g}$

$\mathrm{C}_{\mathrm{e}}=$ the equilibrium concentration of As, $\mathrm{mg} / \mathrm{L}$

$\mathrm{q}_{\max }=$ the maximum adsorption capacity, $\mathrm{mg} / \mathrm{g}$

$\mathrm{K}_{\mathrm{f}}=$ Freundlich constant

$\mathrm{n}=$ Freundlich intensity factor

$\mathrm{b}=$ Langmuir constant

The results for varying adsorbent dosages $(0.1,0.5$ and 1.0) $\mathrm{g} / \mathrm{L}$ and initial As (III) concentrations $(10,20,35$ and 50) $\mathrm{mg} / \mathrm{L}$ were fitted to both the linear and non-linear isotherm models as depicted in Figures 7 and 8 to compute the parametric constants as obtained from these plots and were tabulated in Table 1. It may be observed that maximum adsorption capacity estimated in both cases of non-linear and linear models was found almost same as equal to $263 \mathrm{mg} / \mathrm{g}$. Moreover, it may be concluded from the obtained plots and computation made that Freundlich model fitted better with higher value of R-square. This may be attributed to the multi-layer coverage over a heterogeneous surface with identical sites for adsorption on the surface of nanoparticles. Better fitting to Freundlich as compared to Langmuir model also implies that the adsorption of As (III) over the surface of Fe (III)-Mg (II) binary oxide was dominated by multi-layered rather than mono-layered.
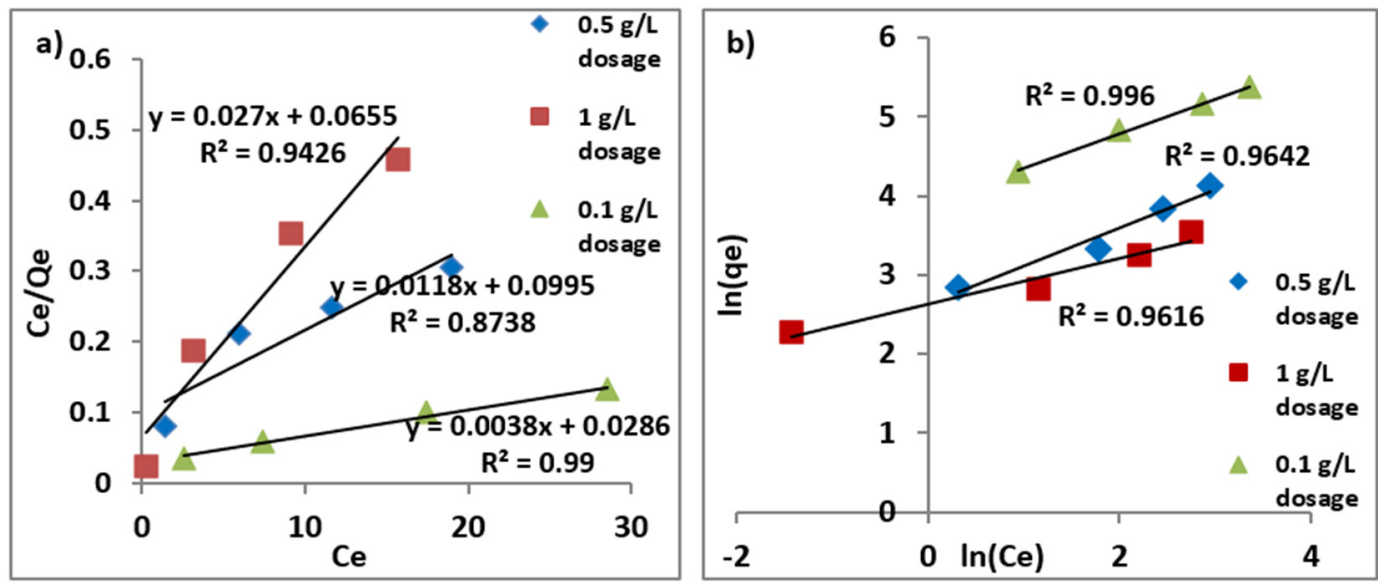

Figure 7. Linear models of (a) Langmuir adsorption isotherm at 0.1, 0.5 and $1.0 \mathrm{~g} / \mathrm{L}$ adsorbent dosages, (b) Freundlich adsorption isotherm at $0.1,0.5$ and $1.0 \mathrm{~g} / \mathrm{L}$ adsorbent dosages.

Table 1. Parametric values obtained from isotherm plots for As (III) adsorption experimental runs at initial pH 6 and room temperature.

\begin{tabular}{|c|c|c|c|c|c|c|c|}
\hline \multirow[t]{2}{*}{ Models } & \multirow[t]{2}{*}{$\begin{array}{c}\text { Adsorbent } \\
\text { Dosage (g/L) }\end{array}$} & \multicolumn{3}{|c|}{ Langmuir Isotherm } & \multicolumn{3}{|c|}{ Freundlich Isotherm } \\
\hline & & $q_{\max }(m g / g)$ & $b$ & $R^{2}$ & $K_{f}$ & $n$ & $R^{2}$ \\
\hline \multirow{3}{*}{ Linear } & 1 & 37.05 & 0.41221 & 0.9426 & 13.92659 & 2.287283 & 0.9616 \\
\hline & 0.5 & 84.75 & 0.1186 & 0.8738 & 13.802 & 2.0492 & 0.9642 \\
\hline & 0.1 & 263.2 & 0.13286 & 0.99 & 50.4761 & 3.460208 & 0.996 \\
\hline \multirow{3}{*}{ Non-linear } & 1 & 40.54 & 0.24854 & 0.819 & 12.42526 & 2.83962 & 0.94786 \\
\hline & 0.5 & 105.15 & 0.07201 & 0.905 & 11.53966 & 1.76192 & 0.96806 \\
\hline & 0.1 & 263.33 & 0.13199 & 0.974 & 52.44399 & 2.36656 & 0.99577 \\
\hline
\end{tabular}



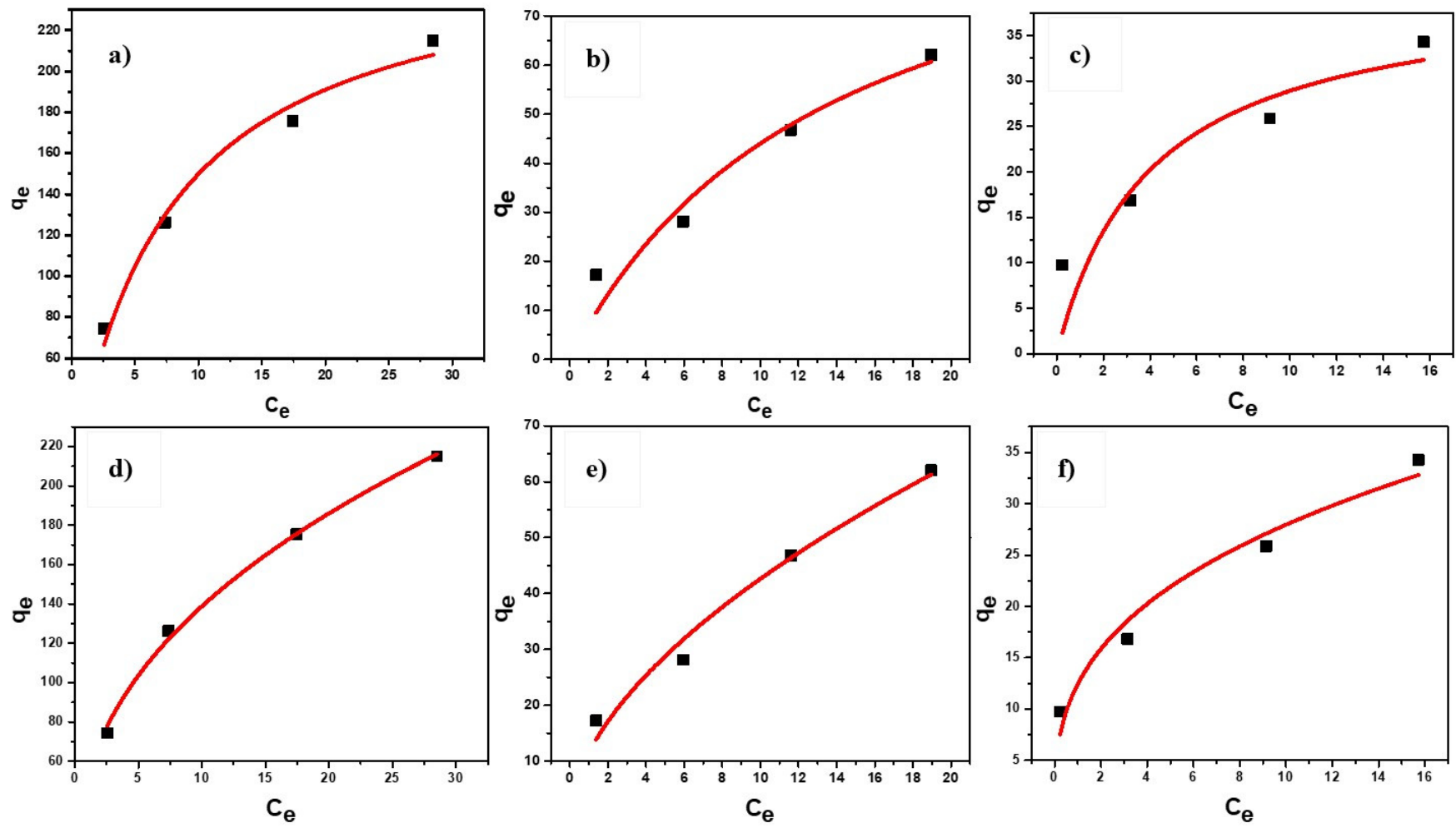

Figure 8. Nonlinear models of Langmuir adsorption isotherm at dosages (a) $0.1 \mathrm{~g} / \mathrm{L}$, (b) $0.5 \mathrm{~g} / \mathrm{L}$, (c) $1.0 \mathrm{~g} / \mathrm{L}$ and Freundlich adsorption isotherm at (d) $0.1 \mathrm{~g} / \mathrm{L},(\mathbf{e}) 0.5 \mathrm{~g} / \mathrm{L},(\mathbf{f}) 1.0 \mathrm{~g} / \mathrm{L}$.

\subsection{Adsorption Kinetics}

Studies on adsorption kinetics were carried out for both pseudo Ist order and IInd order as depicted in Figure 9a,b and was observed as to follow pseudo IInd order kinetics. Supposing that adsorption capacity is proportionate to no. of active adsorption sites in accordance with (Ho and McKay 1999) the Lagergren equation may be expressed as [59]:

$$
\frac{\mathrm{dq}}{\mathrm{dt}}=\mathrm{k}_{\mathrm{ads}}\left(\mathrm{q}_{\mathrm{e}}-\mathrm{q}_{\mathrm{t}}\right)^{2} \quad \mathrm{q}_{\mathrm{t}}=0 \mathrm{at}^{\prime} \mathrm{t}^{\prime}=0,
$$

where $\mathrm{q}_{\mathrm{t}}$ is the amount of As on adsorbent surface at time ' $\mathrm{t}$ ', $\mathrm{k}_{\mathrm{ads}}$ is the adsorption rate constant $\left(\mathrm{g} \mathrm{mg}^{-1} \mathrm{~h}^{-1}\right)$. On integration and rearrangement, the linearized form of pseudo second order rate may be written as follows:

$$
\begin{aligned}
\frac{\mathrm{t}}{\mathrm{q}_{\mathrm{t}}} & =\frac{1}{\mathrm{~h}}+\frac{1}{\mathrm{q}_{\mathrm{e}}} \mathrm{t} \\
\mathrm{h} & =\mathrm{k}_{\mathrm{ads}} \mathrm{q}_{\mathrm{e}^{\prime}}^{2}
\end{aligned}
$$

where $\mathrm{h}$ is the initial adsorption rate $\left(\mathrm{mg} \mathrm{g}^{-1} \mathrm{~h}^{-1}\right)$. The values of $\mathrm{K}_{\mathrm{ads}}$ and $\mathrm{h}$ were found from the slope and intercept of the graphs. The values of $k_{\text {ads }}$ and $h$ obtained were $0.55 \mathrm{~g} \mathrm{mg}^{-1} \mathrm{~h}^{-1}$ and $2.45 \mathrm{mg} \mathrm{g}^{-1} \mathrm{~h}^{-1}$, respectively, for $0.5 \mathrm{~g} / \mathrm{L}$ dosage and $2.21 \mathrm{~g} \mathrm{mg}^{-1} \mathrm{~h}^{-1}$ and $2.29 \mathrm{mg} \mathrm{g}^{-1} \mathrm{~h}^{-1}$, respectively, for $1 \mathrm{~g} / \mathrm{L}$ dosage adsorbent. 

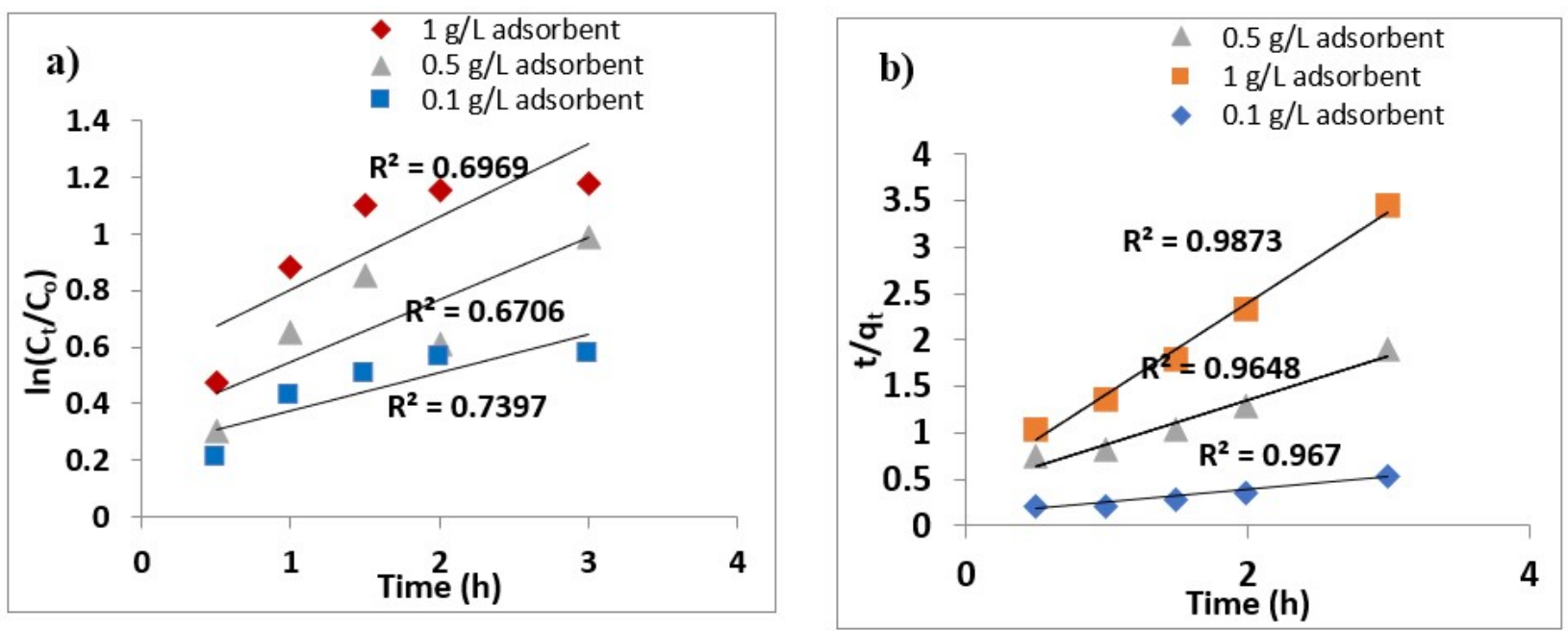

Figure 9. (a) Pseudo-first-order kinetics fitting, (b) pseudo second order kinetics fitting for $50 \mathrm{mg} / \mathrm{L}$ initial concentration of As (III) and adsorbent dosages $0.1,0.5$ and $1 \mathrm{~g} / \mathrm{L}$.

\subsection{Effect of Co-Existing Ions}

Common anions, such as phosphate, sulphate and carbonate, may either compete or interfere with the adsorption of arsenic, as they are generally found in an aqueous medium. So their effect on adsorption was investigated at different As (III) concentrations (10-50 $\left.\mathrm{mg} \mathrm{L}^{-1}\right), \mathrm{pH} 6$ and a fixed adsorbent dose of $0.5 \mathrm{~g} / \mathrm{L}$. The results are shown in Figure 10, signifying that phosphate competes and hinders adsorption of arsenic significantly, which is in accordance with past studies [60-62]. This may be due to the fact that both arsenate and phosphate had similar structural and chemical behavior, thereby getting adsorbed onto iron oxide forming inner sphere complex. At higher initial concentrations, the amount of arsenic adsorption decreases slightly due to inhibition as a result of coexisting ions. Furthermore, phosphate being analogue to arsenate competes well, although arsenate binds strongly onto iron hydroxides due to its larger size [63]. On contrary, carbonate and sulphate were not found to interfere in adsorption.

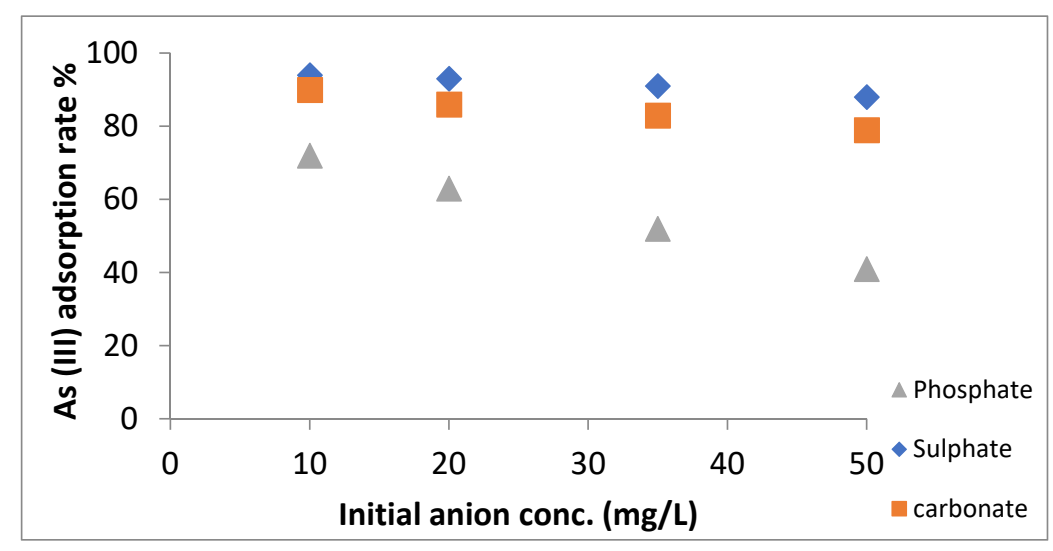

Figure 10. Effect of coexisting ions $\left(\mathrm{PO}_{4}{ }^{3-}, \mathrm{SO}_{4}{ }^{2-}\right.$ and $\left.\mathrm{CO}_{3}{ }^{2-}\right)$ on As (III) adsorption.

\subsection{Comparison of Fe (III)-Mg (II) Binary Oxide with Other Adsorbents}

Table 2 gives a comparative assessment of the maximum arsenic adsorption capacities of recently used adsorbents as reported in the literature under different experimental states. The computed $\mathrm{q}_{\max }$ value $(263.2 \mathrm{mg} / \mathrm{g})$ of prepared binary oxide nanomaterial was found to be much higher than other reported materials for As (III) and As (V) removal. 
Table 2. Arsenic adsorption capacities of few recently used nano-sized adsorbents as reported.

\begin{tabular}{|c|c|c|c|c|}
\hline S. No. & Adsorbents & $\mathrm{pH}$ & $\begin{array}{c}\text { Qe } \\
\left(\mathrm{mg} \mathrm{g}^{-1}\right)\end{array}$ & References \\
\hline$(1)$ & Fe (III)-Mg (II) oxide NPs & 6 & $263.2[$ As (III)] & Present Study \\
\hline (2) & Fe-Zr binary oxide & 7 & $46.1[$ As $(\mathrm{V})]$ & [3] \\
\hline (3) & GNP/Fe-Mg Binary Oxide Composite & 7 & $103.9[$ As $(V)]$ & [16] \\
\hline (4) & Nickel boride nanoparticle-coated resin & 6 & 23.4 [As (III)] & [64] \\
\hline (5) & Ce-Fe mixed oxide MWCNT & 4 & $28.74[$ As $(\mathrm{V})]$ & [65] \\
\hline (6) & ZnOnanorods & 7 & $52.63[$ As $(\mathrm{V})]$ & [66] \\
\hline (7) & Ethylenediamine modified $\mathrm{Fe}_{3} \mathrm{O}_{4} \mathrm{NPs}$ & 2 & $107[$ As (V)] & [67] \\
\hline (8) & Flower like porous $\mathrm{MgO} \mathrm{Np}^{\prime} \mathrm{s}$ & 7 & 252.34 [As (III)] & [68] \\
\hline (9) & $\begin{array}{c}\text { Granular Mn-oxide-doped Al oxide } \\
\text { (GMAO) }\end{array}$ & 7 & 48.52 [As (III)] & [69] \\
\hline$(10)$ & $\begin{array}{l}\text { Magnetic nanoparticle-impregnated } \\
\text { chitosan beads }\end{array}$ & 6.8 & $35.7[$ As $(\mathrm{V})]$ & [70] \\
\hline (11) & Superparamagnetic $\mathrm{Mg}_{0.27} \mathrm{Fe}_{2.5} \mathrm{O}_{4}$ & 7 & 127.4 [As (III)] & [71] \\
\hline
\end{tabular}

\subsection{Reusability of Synthesized Material}

The reusability and regenerative power of synthesized binary oxide nanomaterial was also assessed by rinsing the used adsorbent with $0.1 \mathrm{M} \mathrm{mol} / \mathrm{L}$ of $\mathrm{NaOH}$ solution before drying and desiccating it. Then these nanoparticles were later subjected 2 more adsorption tests for which the results were obtained as shown in Figure 11. Adsorption capacity of regenerated Fe (III)-Mg (II) oxide nanomaterial decreased with the no. of cycles as shown in Figure 11. Although, the reduction in adsorption after Ist and IInd cycle was found to be $23.2 \%$ and $13.5 \%$ respectively, signifying that percent reduction in removal efficiency was quite low after the Ist regenerative cycle.

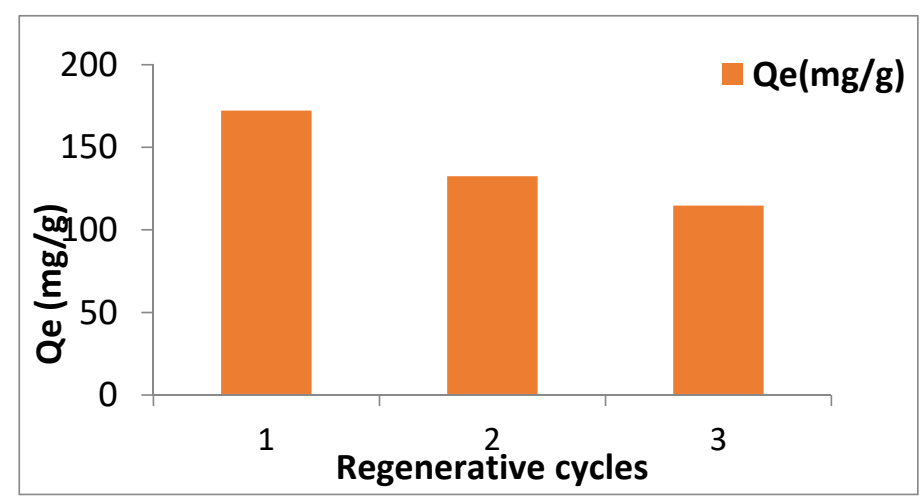

Figure 11. Effect on adsorption capacity of the prepared nanomaterial after regenerative cycles.

\section{Conclusions}

A distinctive Fe (III)-Mg (II) binary metal oxide nanomaterial was synthesized by a simple co-precipitation method. The crystallite size of the prepared nanomaterial was obtained to be $14 \mathrm{~nm}$ as calculated using the Debye-Scherrer equation. The adsorption of As (III) on the prepared nanomaterial was controlled by both the surface charge of Fe (III)-Mg (II) and the form of arsenic species. $\mathrm{pH}$ was found to be an influencing factor in adsorbing arsenic as it decides the feasible $\mathrm{pH}$ range for adsorption to occur along deciding the dominance of particular arsenic species. The adsorption capacity of As (III) was found high in slightly acidic-neutral range and started declining as the solution shifts towards highly basic nature. These results suggest that $\mathrm{pH}$ needs to be optimized around slight acidic conditions; where nanomaterial is highly efficient in uptaking arsenic. Co-existing 
ions of carbonates and sulphates have a negligible effect on arsenic adsorption, except phosphate, which considerably reduces arsenic removal. Moreover, the prepared binary metal oxide nanomaterial could be easily regenerated to be reused. The results were conclusive in proving that prepared binary oxide might be successfully used in treating arsenite present in water supplies.

Author Contributions: Conceptualization, methodology, investigation, writing-original draft and review of the final manuscript, S.U.K. and R.Z.; formal analysis, S.U.K. and R.Z.; resources, supervision and review, F.S., I.H.F. and A.A.; visualization, S.U.K. and R.Z.; review and editing, F.S.; H.A.; F.A.; resources and review, I.H.F. and S.U.K. All authors have read and agreed to the published version of the manuscript.

Funding: This research received no external funding.

Institutional Review Board Statement: Not applicable.

Informed Consent Statement: Not applicable.

Acknowledgments: Authors are thankful for the academic support and resources of the Department of Civil Engineering, Zakir Husain College of Engineering and Technology, Aligarh Muslim University, India. We acknowledge support for the open access fee by Prince Mohammad Bin Fahd University, Al Khobar, Kingdom of Saudi Arabia in the funding program Open Access Publishing.

Conflicts of Interest: The authors declare no conflict of interest.

\section{References}

1. Manning, B.A.; Hunt, M.L.; Amrhein, C.; Yarmoff, J.A. Arsenic (III) and arsenic (V) reactions with zerovalent iron corrosion products. Environ. Sci. Technol. 2002, 36, 5455-5461. [CrossRef] [PubMed]

2. Mohan, D.; Pittman, C.U., Jr. Arsenic removal from water/wastewater using adsorbents—A critical review. J. Hazard. Mater. 2007, 142, 1-53. [CrossRef] [PubMed]

3. Ren, Z.; Zhang, G.; Chen, J.P. Adsorptive removal of arsenic from water by an iron-zirconium binary oxide adsorbent. J. Colloid Interface Sci. 2011, 358, 230-237. [CrossRef]

4. Khan, S.U.; Farooqi, I.H.; Usman, M.; Basheer, F. Energy Efficient Rapid Removal of Arsenic in an Electrocoagulation Reactor with Hybrid Fe/Al Electrodes: Process Optimization Using CCD and Kinetic Modeling. Water 2020, 12, 2876. [CrossRef]

5. Ahmad, A.; Cornelissen, E.; van de Wetering, S.; van Dijk, T.; van Genuchten, C.; Bundschuh, J.; van der Wal, A.; Bhattacharya, P. Arsenite removal in groundwater treatment plants by sequential Permanganate-Ferric treatment. J. Water Process Eng. 2018, 26, 221-229. [CrossRef]

6. Aredes, S.; Klein, B.; Pawlik, M. The removal of arsenic from water using natural iron oxide minerals. J. Clean. Prod. 2013, 60, 71-76. [CrossRef]

7. Mateen, Q.S.; Khan, S.U.; Islam, D.T.; Khan, N.A.; Farooqi, I.H. Copper (II) removal in a column reactor using electrocoagulation: Parametric optimization by response surface methodology using central composite design. Water Environ. Res. 2020, 92, 1350-1362. [PubMed]

8. Polowczyk, I.; Cyganowski, P.; Ulatowska, J.; Sawiński, W.; Bastrzyk, A. Synthetic iron oxides for adsorptive removal of arsenic. Water Air Soil Pollut. 2018, 229, 1-10. [CrossRef] [PubMed]

9. Khan, N.A.; Khan, S.U.; Ahmed, S.; Farooqi, I.H.; Dhingra, A.; Hussain, A.; Changani, F. Applications of nanotechnology in water and wastewater treatment: A review. Asian J. Water Environ. Pollut. 2019, 16, 81-86. [CrossRef]

10. Zaidi, R.; Khan, S.U.; Azam, A.; Farooqi, I.H. A study on effective adsorption of lead from an aqueous solution using Copper Oxide nanoparticles. IOP Conf. Series: Mat. Sci. Eng. 2021, 1058, 012074. [CrossRef]

11. Kalfa, O.M.; Yalçınkaya, Ö.; Türker, A.R. Synthesis of nano $\mathrm{B}_{2} \mathrm{O}_{3} / \mathrm{TiO}_{2}$ composite material as a new solid phase extractor and its application to preconcentration and separation of cadmium. J. Hazard. Mater. 2009, 166, 455-461. [CrossRef] [PubMed]

12. Ali, I. New generation adsorbents for water treatment. Chem. Rev. 2012, 112, 5073-5091. [CrossRef] [PubMed]

13. Ashraf, S.; Siddiqa, A.; Shahida, S.; Qaisar, S. Titanium-based nanocomposite materials for arsenic removal from water: A review. Heliyon 2019, 5, e01577. [CrossRef] [PubMed]

14. Patra, A.K.; Dutta, A.; Bhaumik, A. Self-assembled mesoporousy- $\mathrm{Al}_{2} \mathrm{O}_{3}$ spherical nanoparticles and their efficiency for the removal of arsenic from water. J. Hazard. Mater. 2012, 201, 170-177. [CrossRef]

15. Cui, H.; Li, Q.; Gao, S.; Shang, J.K. Strong adsorption of arsenic species by amorphous zirconium oxide nanoparticles. Ind. Eng. Chem. Res. 2012, 18, 1418-1427. [CrossRef]

16. La, D.D.; Patwari, J.M.; Jones, L.A.; Antolasic, F.; Bhosale, S.V. Fabrication of a GNP/Fe-Mg binary oxide composite for effective removal of arsenic from aqueous solution. ACS Omega 2017, 2, 218-226. [CrossRef]

17. Khan, S.U.; Farooqi, I.H.; Ayub, S. Studies on application of Fe based binary oxide nanoparticles for treatment of lead $\left(\mathrm{Pb}^{2+}\right)$ contaminated water- A batch study. Mater. Today Proc. 2017, 4, 9650-9655. [CrossRef] 
18. Chen, J.; Wang, J.; Zhang, G.; Wu, Q.; Wang, D. Facile fabrication of nanostructured cerium-manganese binary oxide for enhanced arsenite removal from water. Chem. Eng. J. 2018, 334, 1518-1526. [CrossRef]

19. Nikić, J.; Watson, M.A.; Isakovski, M.K.; Tubić, A.; Šolić, M.; Kordić, B.; Agbaba, J. Synthesis, characterization and application of magnetic nanoparticles modified with Fe-Mn binary oxide for enhanced removal of As (III) and As (V). Environ. Technol. 2019, 1-13. [CrossRef]

20. He, K.Q.; Yuan, C.G.; Jiang, Y.H.; Duan, X.L.; Li, Y.; Shi, M.D. Synergistic effects of Fe-Mn binary oxide for gaseous arsenic removal in flue gas. Ecotoxicol. Environ. Saf. 2021, 207, 111491. [CrossRef]

21. Zhang, G.S.; Qu, J.H.; Liu, H.J.; Liu, R.P.; Li, G.T. Removal mechanism of As (III) by a Novel Fe-Mn binary oxide adsorbent: Oxidation and sorption. Environ. Sci. Technol. 2007, 41, 4613-4619. [CrossRef] [PubMed]

22. An, B.; Zhao, D. Immobilization of As (III) in soil and groundwater using a new class of polysaccharide stabilized Fe-Mn oxide nanoparticles. J. Hazard. Mater. 2012, 211, 332-341. [CrossRef] [PubMed]

23. Basu, T.; Ghosh, U.C. Nano-structured iron (III)-cerium (IV) mixed oxide: Synthesis, characterization and arsenic sorption kinetics in the presence of co-existing ions aiming to apply for high arsenic groundwater treatment. Appl. Surf. Sci. 2013, 283, 471-481. [CrossRef]

24. Khan, S.U.; Zaidi, R.; Hassan, S.Z.; Farooqi, I.H.; Azam, A. Application of Fe-cu binary oxide nanoparticles for the removal of hexavalent chromium from aqueous solution. Water Sci. Technol. 2016, 74, 165-175.

25. Wen, Z.; Zhang, Y.; Cheng, G.; Wang, Y.; Chen, R. Simultaneous removal of As (V)/Cr (VI) and acid orange 7 (AO7) by nanosized ordered magnetic mesoporous Fe-Ce bimetal oxides: Behavior and mechanism. Chemosphere 2019, 218, 1002-1013. [CrossRef]

26. Madzokere, T.C.; Karthigeyan, A. Heavy metal ion effluent discharge containment using magnesium oxide (MgO) nanoparticles. Mater. Today Proc. 2017, 4, 9-18. [CrossRef]

27. Yu, Y.; Yu, L.; Chen, J.P. Adsorption of fluoride by Fe-Mg-La triple-metal composite: Adsorbent preparation, illustration of performance and study of mechanisms. Chem. Eng. J. 2015, 262, 839-846. [CrossRef]

28. Yusoff, A.H.; Salimi, M.N.; Jamlos, M.F. A review: Synthetic strategy control of magnetite nanoparticles production. Adv. Nano Res. 2018, 6, 1 .

29. Abimanyu, H.; Kim, C.S.; Ahn, B.S.; Yoo, K.S. Synthesis of dimethyl carbonate by transesterification with various $\mathrm{MgO}_{-} \mathrm{CeO}$ mixed oxide catalysts. Catal. Lett. 2007, 118, 30-35. [CrossRef]

30. Abebe, B.; Ananda Murthy, H.C. Synthesis and characterization of Ti-Fe oxide nanomaterials for lead removal. J. Nanomater. 2018, 2018, 9651039. [CrossRef]

31. Magdalane, C.M.; Kaviyarasu, K.; Vijaya, J.J.; Siddhardha, B.; Jeyaraj, B.; Kennedy, J.; Maaza, M. Evaluation on the heterostructured $\mathrm{CeO}_{2} / \mathrm{Y}_{2} \mathrm{O}_{3}$ binary metal oxide nanocomposites for UV/Vis light induced photocatalytic degradation of Rhodamine-B dye for textile engineering application. J. Alloys Compd. 2017, 727, 1324-1337. [CrossRef]

32. Liu, H.; Deng, S.; Li, Z.; Yu, G.; Huang, J. Preparation of Al-Ce hybrid adsorbent and its application for defluoridation of drinking water. J. Hazard. Mater. 2010, 179, 424-430. [CrossRef]

33. Tsade, H.; Abebe, B.; Murthy, H.A. Nano sized Fe-Al oxide mixed with natural maize cob sorbent for lead remediation. Mater. Res. Express 2019, 6, 085043. [CrossRef]

34. Abebe, B.; Murthy, H.A.; Dessie, Y. Synthesis and characterization of Ti-Fe oxide nanomaterials: Adsorption-degradation of methyl orange dye. Arabian J. Sci. Eng. 2020, 45, 4609-4620. [CrossRef]

35. Khan, M.M.; Khan, W.; Ahamed, M.; Alhazaa, A.N. Microstructural properties and enhanced photocatalytic performance of Zn doped $\mathrm{CeO}_{2}$ nanocrystals. Sci. Rep. 2017, 7, 1-11. [CrossRef] [PubMed]

36. Manyasree, D.; Kiranmayi, P.; Kumar, R. Synthesis, characterization and antibacterial activity of aluminium oxide nanoparticles. Int. J. Pharm. Pharm. Sci. 2018, 10, 32-35.

37. Sahai, A.; Goswami, N.; Kaushik, S.D.; Tripathi, S. $\mathrm{Cu} / \mathrm{Cu}_{2} \mathrm{O} / \mathrm{CuO}$ nanoparticles: Novel synthesis by exploding wire technique and extensive characterization. Appl. Surf. Sci. 2016, 390, 974-983. [CrossRef]

38. Ansari, A.; Ali, A.; Asif, M. Microwave-assisted MgO NP catalyzed one-pot multicomponent synthesis of polysubstituted steroidal pyridines. New J. Chem. 2018, 42, 184-197. [CrossRef]

39. Janet, C.M.; Viswanathan, B.; Viswanath, R.P.; Varadarajan, T.K. Characterization and photoluminescence properties of MgO microtubes synthesized from hydromagnesite flowers. J. Phys. Chem. C 2007, 111, 10267-10272. [CrossRef]

40. Padil, V.V.T.; Černík, M. Green synthesis of copper oxide nanoparticles using gum karaya as a biotemplate and their antibacterial application. Int. J. Nanomed. 2013, 8, 889.

41. Farahmandjou, M.; Soflaee, F. Low temperature synthesis of $\alpha-\mathrm{Fe}_{2} \mathrm{O}_{3}$ nano-rods using simple chemical route. J. Nanostructures 2014, 4, 413-418.

42. Lobato, N.C.C.; Mansur, M.B.; Ferreira, A.D.M. Characterization and chemical stability of hydrophilic and hydrophobic magnetic nanoparticles. Mater. Res. 2017, 20, 736-746. [CrossRef]

43. Huang, X.; Schmucker, A.; Dyke, J.; Hall, S.M.; Retrum, J.; Stein, B.; Remmes, N.; Baxter, D.V.; Dragnea, B.; Bronstein, L.M. Magnetic nanoparticles with functional silanes: Evolution of well-defined shells from anhydride containing silane. J. Mater. Chem. 2009, 19, 4231-4239. [CrossRef] [PubMed]

44. Rufus, A.; Sreeju, N.; Philip, D. Synthesis of biogenic hematite $\left(\alpha-\mathrm{Fe}_{2} \mathrm{O}_{3}\right)$ nanoparticles for antibacterial and nanofluid applications. RSC Adv. 2016, 6, 94206-94217. [CrossRef] 
45. Chowdhury, A.H.; Ghosh, S.; Islam, S.M. Flower-like AgNPs@ m-MgO as an excellent catalyst for $\mathrm{CO}_{2}$ fixation and acylation reactions under ambient conditions. New J. Chem. 2018, 42, 14194-14202. [CrossRef]

46. Mahadevaiah, R.; Lalithamba, H.S.; Shekarappa, S.; Hanumanaika, R. Synthesis of N $\alpha$-protected formamides from amino acids using MgO nano catalyst: Study of molecular docking and antibacterial activity. Sci. Iran. 2017, 24, 3002-3013. [CrossRef]

47. Sutapa, I.W.; Wahab, A.W.; Taba, P.; La Nafie, N. Synthesis and structural profile analysis of the MgO nanoparticles produced through the sol-gel method followed by annealing process. Orient. J. Chem. 2018, 34, 1016. [CrossRef]

48. Hingston, F.J.; Posner, A.M.; Quirk, J.P. Anion adsorption by goethite and gibbsite. J. Soil Sci. 1972, 23, 177-192. [CrossRef]

49. Su, C.; Puls, R.W. Arsenate and arsenite removal by zerovalent iron: Kinetics, redox transformation, and implications for in situ groundwater remediation. Environ. Sci. Technol. 2001, 35, 1487-1492. [CrossRef]

50. Stumm, W. Chemistry of the Solide Water Interface; Wiley-Interscience: New York, NY, USA, 1996.

51. Zeng, H.; Zhai, L.; Qiao, T.; Yu, Y.; Zhang, J.; Li, D. Efficient removal of As (V) from aqueous media by magnetic nanoparticles prepared with Iron-containing water treatment residuals. Sci. Rep. 2020, 10, 1-12.

52. Joshi, S.; Sharma, M.; Kumari, A.; Shrestha, S.; Shrestha, B. Arsenic removal from water by adsorption onto iron oxide/nanoporous carbon magnetic composite. Appl. Sci. 2019, 9, 3732. [CrossRef]

53. Hang, C.; Li, Q.; Gao, S.; Shang, J.K. As (III) and As (V) adsorption by hydrous zirconium oxide nanoparticles synthesized by a hydrothermal process followed with heat treatment. Ind. Eng. Chem. Res. 2012, 51, 353-361. [CrossRef]

54. Mudzielwana, R.; Gitari, M.W.; Ndungu, P. Enhanced As (III) and As (V) adsorption from aqueous solution by a clay based hybrid sorbent. Front. Chem. 2020, 7, 913. [CrossRef]

55. Mahmood, T.; Aslam, M.; Naeem, A.; Siddique, T.; Din, S.U. Adsorption of As (III) from aqueous solution onto iron impregnated used tea activated carbon: Equilibrium, kinetic and thermodynamic study. J. Chil. Chem. Soc. 2018, 63, 3855-3866. [CrossRef]

56. Esposito, A.; Pagnanelli, F.; Lodi, A.; Solisio, C.; Veglio, F. Biosorption of heavy metals by Sphaerotilusnatans: An equilibrium study at different $\mathrm{pH}$ and biomass concentrations. Hydrometallurgy 2001, 62, 129-141. [CrossRef]

57. Wang, J.; Guo, X. Adsorption isotherm models: Classification, physical meaning, application and solving method. Chemosphere 2020, 258, 127279. [CrossRef] [PubMed]

58. Khan, S.U.; Mahtab, M.S.; Farooqi, I.H. Enhanced lead (II) removal with low energy consumption in an electrocoagulation column employing concentric electrodes: Process optimisation by RSM using CCD. Int. J. Environ. Anal. Chem. 2021, 1-18. [CrossRef]

59. Ho, Y.S.; McKay, G. Pseudo-second order model for sorption processes. Process Biochem. 1999, 34, 451-465. [CrossRef]

60. Khownpurk, P.; Chandra-Ambhorn, W. As (III) removal under the presence of competitive anions using the calcined ground oyster shell as the adsorbent. Sep. Sci. Technol. 2020, 55, 395-405. [CrossRef]

61. Kanel, S.R.; Manning, B.; Charlet, L.; Choi, H. Removal of arsenic (III) from groundwater by nanoscale zero-valent iron. Environ. Sci. Technol. 2005, 39, 1291-1298. [CrossRef]

62. O'reilly, S.E.; Strawn, D.G.; Sparks, D.L. Residence time effects on arsenate adsorption/desorption mechanisms on goethite. Soil Sci. Soc. Am. J. 2001, 65, 67-77. [CrossRef]

63. Tuutijärvi, T.; Repo, E.; Vahala, R.; Sillanpää, M.; Chen, G. Effect of competing anions on arsenate adsorption onto maghemite nanoparticles. Chin. J. Chem. Eng. 2012, 20, 505-514. [CrossRef]

64. Çiftçi, T.D.; Henden, E. Nickel/nickel boride nanoparticles coated resin: A novel adsorbent for arsenic(III) and arsenic(V) removal. Powder Technol. 2015, 269, 470-480. [CrossRef]

65. Chen, B.; Zhu, Z.; Ma, J.; Qiu, Y.; Chen, J. Surfactant assisted Ce-Fe mixed oxide decorated multiwalled carbon nanotubes and their arsenic adsorption performance. J. Mater. Chem. A 2013, 1, 11355-11367. [CrossRef]

66. Yuvaraja, G.; Prasad, C.; Vijaya, Y.; Subbaiah, M.V. Application of ZnO nanorods as an adsorbent material for the removal of As (III) from aqueous solution: Kinetics, isotherms and thermodynamic studies. Int. J. Ind. Chem. 2018, 9, 17-25. [CrossRef]

67. Zhang, W.; Liu, C.; Zheng, T.; Ma, J.; Zhang, G.; Ren, G.; Wang, L.; Liu, Y. Efficient oxidation and sorption of arsenite using a novel titanium (IV)-manganese (IV) binary oxide sorbent. J. Hazard. Mater. 2018, 353, 410-420. [CrossRef]

68. Yu, X.Y.; Luo, T.; Jia, Y.; Zhang, Y.X.; Liu, J.H.; Huang, X.J. Porous hierarchically micro-/nanostructured MgO: Morphology control and their excellent performance in As (III) and As (V) removal. J. Phys. Chem. C 2018, 115, 22242-22250. [CrossRef]

69. Wu, K.; Zhang, J.; Chang, B.; Liu, T.; Zhang, F.; Jin, P.; Wang, W.; Wang, X. Removal of arsenic (III, V) by a granular Mnoxide-doped Al oxide adsorbent: Surface characterization and performance. Environ. Sci. Pollut. Res. 2017, 24, 18505-18519. [CrossRef]

70. Wang, J.; Xu, W.; Chen, L.; Huang, X.; Liu, J. Preparation and evaluation of magnetic nanoparticles impregnated chitosan beads for arsenic removal from water. Chem. Eng. J. 2014, 251, 25-34. [CrossRef]

71. Tang, W.; Su, Y.; Li, Q.; Gao, S.; Shang, J.K. Superparamagnetic magnesium ferrite nanoadsorbent for effective arsenic (III, V) removal and easy magnetic separation. Water Res. 2013, 47, 3624-3634. [CrossRef] 